\title{
Evaluation of the biological activity of novel monocationic fluoroaryl-2,2'-bichalcophenes and their analogues
}

This article was published in the following Dove Press journal:

Drug Design, Development and Therapy

17 July 2014

Number of times this article has been viewed

\begin{abstract}
Warda A Hussin $1,2, *, \dagger$
Mohamed A Ismail ${ }^{1,3, *}$

Abdullah M Alzahrani'

Wael M El-Sayed ${ }^{1,4}$

'King Faisal University, College of Science, Departments of Chemistry and Biological Sciences, Hofuf, Saudi Arabia; ${ }^{2} \mathrm{Al}-\mathrm{Azhr}$ University, Faculty of Science, Department of Botany and Microbiology, Cairo, Egypt; ${ }^{3}$ Department of Chemistry, Faculty of Science, Mansoura University, Mansoura, Egypt; ${ }^{4}$ University of Ain Shams, Faculty of Science, Department of Zoology, Abbassia, Cairo, Egypt
\end{abstract}

*These authors contributed equally to this work

tWarda A Hussin passed away on May 21,2014
Correspondence: Mohamed Ismail Department of Chemistry, College of Science, King Faisal University, PO Box 380, Hofuf 31982, Saudi Arabia Tel +966533543735

Email mabouelenan@kfu.edu.sa
Abstract: A series of bichalcophene fluorobenzamidines 5a-e was synthesized from the corresponding mononitriles $4 \mathrm{a}-\mathrm{e}$ via a direct reaction with lithium bis(trimethylsilyl)amide LiN(TMS) followed by de-protection with ethanolic $\mathrm{HCl}$ (gas). Bichalcophene fluorobenzonitriles 4a-e were prepared adopting a Stille coupling reaction between the bromo compounds $3 \mathrm{a}-\mathrm{c}$ and 2-(tri- $n$-butylstannyl)furan or analogues. As an approach to drug discovery, the structureantimutagenicity relationship of novel fluoroarylbichalcophenes was examined using the Ames Salmonella/microsomal assay. At nontoxic concentrations (10 and $20 \mu \mathrm{M})$, all derivatives alone or in combination with sodium azide $\left(\mathrm{NaN}_{3} ; 2 \mu \mathrm{g} /\right.$ plate $)$ or benzo[a]pyrene $(\mathrm{B}[\mathrm{a}] \mathrm{P} ; 20 \mu \mathrm{M})$ in the presence of $\mathrm{S} 9 \mathrm{mix}$ were not mutagenic. The fluoroaryl derivatives significantly reduced the $\mathrm{NaN}_{3}$-induced and $\mathrm{B}[\mathrm{a}] \mathrm{P}$-induced mutagenicity under pre-exposure and co-exposure conditions. The recorded antimutagenic activity of fluoroaryl derivatives varied depending on the kind of mutagen and the exposure regimen. Monocationic fluoroarylbichalcophenes were superior to the corresponding mononitriles in reducing $\mathrm{B}[\mathrm{a}] \mathrm{P}$-induced mutagenicity. Nevertheless, mononitriles were more active against $\mathrm{NaN}_{3}$, especially at low concentrations and under pre-exposure treatments. The antimutagenic activity was congruent with a high antioxidant activity that could promote the DNA repair system. The fluorine substitution changed the antimutagenic signature of bichalcophenes. Some of these compounds could be selected for further anticancer studies. Keywords: fluoroaryl-2,2'-bichalcophenes, stille coupling, Salmonella typhimurium, sodium azide, benzo[a]pyrene, antimutagenicity

\section{Introduction}

New anticancer compounds without undesirable side effects are urgently needed. Aromatic diamidines, such as pentamidine, are used extensively against several human ailments. ${ }^{1,2}$ However, some pentamidine derivatives have been withdrawn from further human trials due to associated renal and hepatic toxicities. ${ }^{3}$ A series of furamidine derivatives was synthesized by replacing the phenyl group(s) with pyridyl group(s). Several of these aza-analogues were more active than the furamidine itself. ${ }^{4,5}$ Recently, bifuran diamidine I (Figure 1) has been shown to recognize G-quadruplex DNA. ${ }^{6}$ More recently, monocationic bifuran II was proven to be more effective against methicillin-resistant Staphylococcus aureus infection in mice than was vancomycin. ${ }^{7}$ Promising antimutagenic activity against sodium azide $\left(\mathrm{NaN}_{3}\right)$ and benzo[a]pyrene $(\mathrm{B}[\mathrm{a}] \mathrm{P})$-induced mutagenicity was shown for many of these bichalcophenes. ${ }^{8}$ Although thiophene and furan rings are known for their broad biological activities, ${ }^{9}$ we have shown that replacing the furan ring with a thiophene ring increased the activity. ${ }^{10}$ To improve the pharmacological properties, and as an approach to drug discovery of 

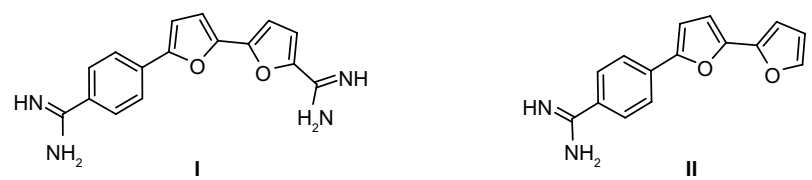

Figure I Structure of some biologically important cationic bichalcophene compounds. Notes: Compound I is 5 '-(4-amidinophenyl)-2,2'-bifuran-5-carboxamidine. Compound II is $4-\left(2,2^{\prime}\right.$-bifuran-5-yl)benzamidine.

the previously investigated compounds, we synthesized a series of fluoroarylbichalcophenes. Fluorine substitution can alter the biological and chemical properties of compounds, and this led to the development of a vast number of novel fluorinated drugs. The high electronegativity of fluorine substituent can modify the electron distribution in a molecule, which affects its absorption, distribution, and metabolism. ${ }^{11}$ The presence of a fluorine atom usually increases lipophilicity and hence biological availability. ${ }^{12}$ Through microsomal inhibition, fluorine substitution was shown to abolish quinolone mutagenicity. ${ }^{13}$

Novel potential drugs are usually screened for their possible toxicity and mutagenic and antimutagenic activities in many systems, including the Salmonella/microsomal assay. There is a strong relation between mutagenicity in Salmonella and carcinogenicity in animal models. ${ }^{14}$ Given that introduction of a fluorine atom onto a molecule modifies its mutagenic potency, ${ }^{15}$ we investigated the structure-mutagenicity relationship profile of fluoroarylbichalcophenes and the effect of fluorine on their antimutagenic potency using the Ames Salmonella/microsomal assay. We also investigated the antioxidant activity of these novel compounds.

\section{Materials and methods}

\section{Chemistry}

Melting points were recorded using a Gallenkamp meltingpoint apparatus and were uncorrected. Thin-layer chromatography analysis was carried out on silica gel $60 \mathrm{~F}_{254}$ pre-coated aluminum sheets and detected under ultraviolet light. Infrared (IR) spectra were recorded using the potassium bromide (KBr) wafer technique on a Shimadzu 5800 Fourier transform (FT)-IR spectrometer. ${ }^{1} \mathrm{H}$ nuclear magnetic resonance (NMR) spectra were recorded employing a Varian Mercury VX-300 spectrometer, and chemical shifts $(\delta)$ were in parts per million (ppm) relative to tetramethylsilane (TMS) as the internal standard. Mass spectra were recorded on a gas chromatography-mass spectrometry (GC-MS) (Schimadzu QP-1000 EX) spectrometer. Elemental analyses were performed at the micro-analytical laboratories of the Faculty of Science, Cairo University (Cairo, Egypt) and are within \pm 0.4 of the theoretical values. All chemicals and solvents were purchased from Aldrich Chemical Co (St Louis, MO, USA). $N$-Bromosuccinimide (NBS) was recrystallized from nitromethane prior to use. All solvents were reagent grade.

\section{Procedure for preparation}

of fluoroarylchalcophene carbonitriles $2 a-c$

\section{3-Fluoro-4-(furan-2-yl)benzonitrile (2a)}

A mixture of 4-bromo-3-fluorobenzonitrile 1a (3.98 g, $20 \mathrm{mmol}$ ), 2-(tri- $n$-butylstannyl)furan (7.15 g, $20 \mathrm{mmol}$ ), and tetrakis(triphenylphosphine) palladium $(300 \mathrm{mg})$ in dry dioxane $(20 \mathrm{~mL})$ was heated under nitrogen at reflux $\left(90^{\circ} \mathrm{C}-100^{\circ} \mathrm{C}\right)$ for 24 hours. The solvent was evaporated under reduced pressure, the solid was dissolved in ethyl acetate, and the solution was passed through celite to remove $\mathrm{Pd}$. The solution was evaporated, and the solid was collected to give $2 \mathrm{a}$ as an offwhite solid in $83 \%$ yield, $\mathrm{mp} 73^{\circ} \mathrm{C}-73.5^{\circ} \mathrm{C}$ (hexanes). Rate of flow $\left(\mathrm{R}_{\mathrm{f}}\right)=0.71$, petroleum ether $\left(40^{\circ} \mathrm{C}-60^{\circ} \mathrm{C}\right)$-EtOAc $(95: 5)$. IR (KBr) v' 3117, 3083, 3058 (CH), 2229 (CN), 1643, 1617, $1585(\mathrm{C}=\mathrm{C}) \mathrm{cm}^{-1} .{ }^{1} \mathrm{H}$ NMR $\left(\mathrm{CDCl}_{3}\right) ; \delta$ 6.57-6.59 (m, 1H), 7.01-7.04 (m, 1H), 7.39-7.58 (m, 3H), 7.93 (t, J=7.8 Hz, 1H). Anal Calcd for $\mathrm{C}_{11} \mathrm{H}_{6}$ FNO: C 70.59; H 3.23; N 7.48. Found: C 70.65; H 3.14; N 7.31.

\section{2-Fluoro-4-(furan-2-yl)benzonitrile (2b)}

A white solid in $74 \%$ yield, mp $77^{\circ} \mathrm{C}-78^{\circ} \mathrm{C}$ (hexanes). $\mathrm{R}_{\mathrm{f}}=0.52$, petroleum ether $\left(40^{\circ} \mathrm{C}-60^{\circ} \mathrm{C}\right)$-EtOAc $(95: 5)$. IR (KBr) v' 3113, 3076, $3045(\mathrm{CH}), 2232(\mathrm{CN}), 1620,1559$ $(\mathrm{C}=\mathrm{C}) \mathrm{cm}^{-1} .{ }^{1} \mathrm{H}$ NMR $\left(\mathrm{CDCl}_{3}\right) ; \delta$ 6.54-6.56 (m, 1H), $6.86(\mathrm{~d}, \mathrm{~J}=3.3 \mathrm{~Hz}, 1 \mathrm{H}), 7.46-7.64$ (m, 4H). Anal Calcd for $\mathrm{C}_{11} \mathrm{H}_{6} \mathrm{FNO}$ : $\mathrm{C} 70.59$; $\mathrm{H}$ 3.23; N 7.48. Found: C 70.51; H 3.18; N 7.65 .

\section{2-Fluoro-4-(thiophen-2-yl)benzonitrile (2c)}

A yellow solid in $81 \%$ yield, mp $99^{\circ} \mathrm{C}-99.5^{\circ} \mathrm{C}$ (hexanes). $\mathrm{R}_{\mathrm{f}}=0.55$, petroleum ether $\left(40^{\circ} \mathrm{C}-60^{\circ} \mathrm{C}\right)$-EtOAc (95:5). IR (KBr) v'3120, $3081(\mathrm{CH}), 2227(\mathrm{CN}), 1614,1557(\mathrm{C}=\mathrm{C})$ $\mathrm{cm}^{-1} .{ }^{1} \mathrm{H}$ NMR $\left(\mathrm{CDCl}_{3}\right) ; \delta 7.12-7.14(\mathrm{~m}, 1 \mathrm{H}), 7.40-7.48$ (m, 4H), 7.58-7.61 (m, 1H). MS (EI) m/e (rel int); 203 $\left(\mathrm{M}^{+}, 100\right), 171$ (6), 158 (15). Anal Calcd for $\mathrm{C}_{11} \mathrm{H}_{6} \mathrm{FNS}$ : C 65.01; H 2.98; N 6.89. Found: C 64.78; H 3.07; N 6.93.

\section{Procedure for preparation}

\section{of bromochalcophenes $3 \mathrm{a}-\mathrm{c}$}

4-(5-Bromofuran-2-yl)-3-fluorobenzonitrile (3a)

To a solution of $2 \mathrm{a}(2.81 \mathrm{~g}, 15 \mathrm{mmol})$ in dimethylformamide (DMF) (15 mL), we added portion-wise NBS (2.67 g, $15 \mathrm{mmol}$ ) with stirring. The reaction mixture was stirred overnight at room temperature, and then poured onto 
cold water. The precipitate formed was collected, washed with water, and dried to give $3 \mathrm{a}$ as a red-pink powder in $91 \%$ yield, $\mathrm{mp} 138^{\circ} \mathrm{C}-138.5^{\circ} \mathrm{C}(\mathrm{EtOH}) . \mathrm{R}_{\mathrm{f}}=0.68$, petroleum ether $\left(40^{\circ} \mathrm{C}-60^{\circ} \mathrm{C}\right)$-EtOAc (95:5). IR (KBr) v' 3095, 3074, $3052(\mathrm{CH}), 2228(\mathrm{CN}), 1615,1558(\mathrm{C}=\mathrm{C}) \mathrm{cm}^{-1} .{ }^{1} \mathrm{H} \mathrm{NMR}$ $\left(\mathrm{DMSO}-d_{6}\right) ; \delta 6.86(\mathrm{~d}, \mathrm{~J}=3.0 \mathrm{~Hz}, 1 \mathrm{H}), 7.11(\mathrm{~d}, \mathrm{~J}=3.0 \mathrm{~Hz}$, 1H), $7.76(\mathrm{~d}, \mathrm{~J}=8.1 \mathrm{~Hz}, 1 \mathrm{H}), 7.89-8.00(\mathrm{~m}, 2 \mathrm{H})$. Anal Calcd for $\mathrm{C}_{11} \mathrm{H}_{5} \mathrm{BrFNO}$ : C 49.65; $\mathrm{H} 1.89$; N 5.26. Found: C 49.31; H 2.12; N 5.03 .

\section{4-(5-Bromofuran-2-yl)-2-fluorobenzonitrile (3b)}

A pink powder in $86 \%$ yield, mp $123^{\circ} \mathrm{C}-124^{\circ} \mathrm{C}(\mathrm{EtOH})$. $\mathrm{R}_{\mathrm{f}}=0.43$, petroleum ether $\left(40^{\circ} \mathrm{C}-60^{\circ} \mathrm{C}\right)$-EtOAc (95:5). IR (KBr) v' $3109(\mathrm{CH}), 2233(\mathrm{CN}), 1618,1553(\mathrm{C}=\mathrm{C}) \mathrm{cm}^{-1}$. ${ }^{1} \mathrm{H} \mathrm{NMR}\left(\mathrm{CDCl}_{3}\right) ; \delta 6.47(\mathrm{~d}, \mathrm{~J}=3.0 \mathrm{~Hz}, 1 \mathrm{H}), 6.80(\mathrm{~d}, \mathrm{~J}=3.0 \mathrm{~Hz}$, $1 \mathrm{H}), 7.42-7.48(\mathrm{~m}, 2 \mathrm{H}), 7.59-7.62(\mathrm{~m}, 1 \mathrm{H})$. MS (EI) m/e (rel int); $266\left(\mathrm{M}^{+}, 6\right), 267\left(\mathrm{M}^{+}+1,43\right), 158$ (100).

\section{4-(5-Bromothiophen-2-yl)-2-fluorobenzonitrile (3c)}

A pale-yellow powder in $89 \%$ yield, mp $108^{\circ} \mathrm{C}-109^{\circ} \mathrm{C}$ $(\mathrm{EtOH}) . \mathrm{R}_{\mathrm{f}}=0.47$, petroleum ether $\left(40^{\circ} \mathrm{C}-60^{\circ} \mathrm{C}\right)$-EtOAc (95:5). IR (KBr) v'3120, $3083(\mathrm{CH}), 2232(\mathrm{CN}), 1615$, $1560(\mathrm{C}=\mathrm{C}) \mathrm{cm}^{-1} .{ }^{1} \mathrm{H}$ NMR $\left(\mathrm{CDCl}_{3}\right) ; \delta 7.09-7.16(\mathrm{~m}, 2 \mathrm{H})$, 7.31-7.47 (m, 2H), 7.58-7.61 (m, 1H). MS (EI) m/e (rel int); $282\left(\mathrm{M}^{+}, 15\right), 283\left(\mathrm{M}^{+}+1,100\right), 158(81)$.

\section{General procedure for bichalcophene fluorobenzonitrile synthesis $4 a-e$ 4-(2,2'-Bifuran-5-yl)-3-fluorobenzonitrile (4a)}

Adopting the same procedure used for the preparation of $2 \mathrm{a}$, a Stille coupling reaction was performed using bromo compound $3 \mathrm{a}$ to furnish bifuran fluorobenzonitrile $4 \mathrm{a}$ as a golden-yellow solid in $73 \%$ yield, mp $127^{\circ} \mathrm{C}-127.5^{\circ} \mathrm{C}(\mathrm{EtOH} /$ petroleum ether). $\mathrm{R}_{\mathrm{f}}=0.72$, petroleum ether $\left(40^{\circ} \mathrm{C}-60^{\circ} \mathrm{C}\right)$ EtOAc (9:1). IR (KBr) v' 3131, 3080 (CH), 2234 (CN), 1616, $1575(\mathrm{C}=\mathrm{C}) \mathrm{cm}^{-1} .{ }^{1} \mathrm{H}$ NMR (DMSO- $\left.d_{6}\right) ; \delta$ 6.67-6.69 $(\mathrm{m}, 1 \mathrm{H}), 6.93(\mathrm{~d}, \mathrm{~J}=3.3 \mathrm{~Hz}, 1 \mathrm{H}), 6.98(\mathrm{~d}, \mathrm{~J}=3.3 \mathrm{~Hz}, 1 \mathrm{H})$, 7.17-7.20 (m, 1H), 7.78-7.84 (m, 2H), 7.97-8.08 (m, 2H). MS (EI) m/e (rel int); $253\left(\mathrm{M}^{+}, 100\right), 254\left(\mathrm{M}^{+}+1,17\right), 224$ (15), 196 (29). Anal Calcd for $\mathrm{C}_{15} \mathrm{H}_{8} \mathrm{FNO}_{2}$ : C 71.14; H 3.18; N 5.53. Found: C 70.81; H 3.35; N 5.37.

\section{4-(2,2'-Bifuran-5-yl)-2-fluorobenzonitrile (4b)}

A golden-yellow solid in $77 \%$ yield, mp $130^{\circ} \mathrm{C}-131^{\circ} \mathrm{C}(\mathrm{EtOH} /$ petroleum ether). $\mathrm{R}_{\mathrm{f}}=0.51$, petroleum ether $\left(40^{\circ} \mathrm{C}-60^{\circ} \mathrm{C}\right)$ EtOAc (9:1). IR (KBr) v' 3128, $3090(\mathrm{CH}), 2229(\mathrm{CN})$, 1616, $1579(\mathrm{C}=\mathrm{C}) \mathrm{cm}^{-1} .{ }^{1} \mathrm{H}$ NMR (DMSO- $\left.d_{6}\right) ; \delta$ 6.66-6.68 $(\mathrm{m}, 1 \mathrm{H}), 7.45$ (d, J=3.9 Hz, 1H), 6.89 (d, J=3.9 Hz, 1H),
6.97 (d, J=3.0 Hz, 1H), 7.74-7.98 (m, 4H). MS (EI) m/e (rel int); $253\left(\mathrm{M}^{+}, 100\right), 254\left(\mathrm{M}^{+}+1,17\right), 224$ (19), 196 (30). Anal Calcd for $\mathrm{C}_{15} \mathrm{H}_{8} \mathrm{FNO}_{2}$ : C 71.14; H 3.18; N 5.53. Found: C 71.02; H 3.25; N 5.57.

3-Fluoro-4-(5-(thiophen-2-yl)furan-2-yl)benzonitrile (4c) A yellow solid in $68 \%$ yield, mp $124^{\circ} \mathrm{C}-125^{\circ} \mathrm{C}(\mathrm{EtOH} /$ petroleum ether). $\mathrm{R}_{\mathrm{f}}=0.70$, petroleum ether $\left(40^{\circ} \mathrm{C}-60^{\circ} \mathrm{C}\right)$ EtOAc (9:1). IR (KBr) v'3105, $3078(\mathrm{CH}), 2228(\mathrm{CN}), 1613$, $1598(\mathrm{C}=\mathrm{C}) \mathrm{cm}^{-1} .{ }^{1} \mathrm{H}$ NMR $\left(\mathrm{DMSO}-d_{6}\right) ; \delta 7.01(\mathrm{~d}, \mathrm{~J}=3.9 \mathrm{~Hz}$, 1H), 7.16-7.20 (m, 2H), 7.60 (d, J=3.9 Hz, 1H), 7.65 (d, J=3.9 $\mathrm{Hz}, 1 \mathrm{H}), 7.78-7.81(\mathrm{~m}, 1 \mathrm{H}), 7.96-8.05$ (m, 2H). MS (EI) m/e (rel int); $269\left(\mathrm{M}^{+}, 100\right), 270\left(\mathrm{M}^{+}+1,94\right), 253$ (22), 240 (91), 222 (11). Anal Calcd for $\mathrm{C}_{15} \mathrm{H}_{8} \mathrm{FNOS}$ : C 66.90; H 2.99; N 5.20. Found: C 67.04; H 3.08; N 5.15.

2-Fluoro-4-(5-(thiophen-2-yl)furan-2-yl)benzonitrile (4d) A yellow solid in $71 \%$ yield, mp $149^{\circ} \mathrm{C}-149.5^{\circ} \mathrm{C}(\mathrm{EtOH} /$ petroleum ether). $\mathrm{R}_{\mathrm{f}}=0.63$, petroleum ether $\left(40^{\circ} \mathrm{C}-60^{\circ} \mathrm{C}\right)$ EtOAc (9:1). IR (KBr) v' 3105, 3085 (CH), $2227(\mathrm{CN})$, 1619, $1597(\mathrm{C}=\mathrm{C}) \mathrm{cm}^{-1} .{ }^{1} \mathrm{H}$ NMR (DMSO-d $) ; \delta 6.97$ $(\mathrm{d}, \mathrm{J}=3.3 \mathrm{~Hz}, 1 \mathrm{H}), 7.15-7.18(\mathrm{~m}, 1 \mathrm{H}), 7.44(\mathrm{~d}, \mathrm{~J}=3.9 \mathrm{~Hz}$, 1H), 7.57-7.64 (m, 3H), 7.72-7.98 (m, 2H). MS (EI) m/e (rel int); $269\left(\mathrm{M}^{+}, 100\right), 270\left(\mathrm{M}^{+}+1,18\right), 253$ (2), 240 (20). Anal Calcd for $\mathrm{C}_{15} \mathrm{H}_{8}$ FNOS: C 66.90; H 2.99; N 5.20. Found: C 66.93; H 3.11; N 5.13.

\section{4-(2,2'-Bithiophen-5-yl)-2-fluorobenzonitrile (4e)}

A yellow solid in $76 \%$ yield, mp $155^{\circ} \mathrm{C}-156^{\circ} \mathrm{C}(\mathrm{EtOH} /$ petroleum ether). $\mathrm{R}_{\mathrm{f}}=0.70$, petroleum ether $\left(40^{\circ} \mathrm{C}-60^{\circ} \mathrm{C}\right)$ EtOAc (9:1). IR (KBr) v'3102, $3080(\mathrm{CH}), 2227(\mathrm{CN}), 1612$, $1554(\mathrm{C}=\mathrm{C}) \mathrm{cm}^{-1} .{ }^{1} \mathrm{H}$ NMR $\left(\mathrm{DMSO}-d_{6}\right) ; \delta 7.10-7.12(\mathrm{~m}, 1 \mathrm{H})$, 7.39-7.40 (m, 1H), 7.57 (d, J=4.2 Hz, 1H), 7.63-7.65 (m, 1H), 7.79 (d, J=3.9 Hz, 1H), 7.86-7.92 (m, 3H). MS (EI) m/e (rel int); $285\left(\mathrm{M}^{+}, 100\right), 240$ (10). Anal Calcd for $\mathrm{C}_{15} \mathrm{H}_{8} \mathrm{FNS}_{2}$ : C 63.13; H 2.83; N 4.91. Found: C 62.91; H 2.80; N 4.67.

\section{General procedure for bichalcophene fluorobenzamidine synthesis $5 \mathrm{a}-\mathrm{e}$ 4-(2,2'-Bifuran-5-yl)-3-fluorobenzamidine hydrochloride salt (5a)}

The bifuran mononitrile 4a (381 mg, $1.5 \mathrm{mmol})$, suspended in freshly distilled tetrahydrofuran (THF) $(8 \mathrm{~mL})$, was treated with $\mathrm{LiN}(\mathrm{TMS})_{2}$ (1M solution in THF, $4 \mathrm{~mL}, 4 \mathrm{mmol}$ ), and the reaction was allowed to stir overnight. The reaction mixture was then cooled to $0^{\circ} \mathrm{C}$ and a hydrogen chloride ethanolic solution (12 mL, 1.25 M) was added, whereupon a precipitate started forming. The mixture was left to run 
overnight, whereafter it was diluted with ether and the resultant solid was collected by filtration. The monoamidine was purified by neutralization with $1 \mathrm{~N} \mathrm{NaOH}$, followed by filtration of the resultant solid and washing with water $(3 \times 8 \mathrm{~mL})$. Finally, the free base was stirred with hydrogen chloride ethanolic solution overnight and diluted with ether; the solid formed was filtered and dried to furnish the monoamidine 5a hydrochloride salt as a yellow solid in 69\% yield, $\operatorname{mp} 302^{\circ} \mathrm{C}-304^{\circ} \mathrm{C}\left(\mathrm{EtOH} / \mathrm{H}_{2} \mathrm{O}\right)$. IR (KBr) v' 3343,3266 (NH, $\left.\mathrm{NH}_{2}\right)$, 3060, $3038(\mathrm{CH}), 1667,1617(\mathrm{C}=\mathrm{N}, \mathrm{NH}$ bending, $\mathrm{C}=\mathrm{C}) \mathrm{cm}^{-1} .{ }^{1} \mathrm{H}$ NMR (DMSO- $\left.d_{6}\right) ; \delta 6.67-6.69(\mathrm{~m}, 1 \mathrm{H})$, 6.94 (d, J=3.6 Hz, 1H), 7.00 (d, J=3.6 Hz, 1H), 7.18-7.21 (m, 1H), 7.80-7.94 (m, 3H), 8.10 (t, J=7.8 Hz, 1H), 9.44 (br s, 4H, exchangeable with $\mathrm{D}_{2} \mathrm{O}$ ). MS (EI) m/e (rel int); $270\left(\mathrm{M}^{+}, 100\right), 271\left(\mathrm{M}^{+}+1,18\right), 254$ (26), 253 (10). Anal Calcd for $\mathrm{C}_{15} \mathrm{H}_{11} \mathrm{FN}_{2} \mathrm{O}_{2}-1.0 \mathrm{HCl}$ : C 58.73; H 3.94; N 9.13. Found: C 58.67; H 4.16; N 8.92.

\section{4-(2,2'-Bifuran-5-yl)-2-fluorobenzamidine} hydrochloride salt (5b)

A yellow solid in $65 \%$ yield, mp $277^{\circ} \mathrm{C}-278.5^{\circ} \mathrm{C}(\mathrm{EtOH} /$ $\left.\mathrm{H}_{2} \mathrm{O}\right)$. IR ( $\left.\mathrm{KBr}\right)$ v' 3360, 3298, $3193\left(\mathrm{NH}, \mathrm{NH}_{2}\right), 3117,3092$ (CH), 1679, $1619(\mathrm{C}=\mathrm{N}, \mathrm{NH}$ bending, $\mathrm{C}=\mathrm{C}) \mathrm{cm}^{-1} \cdot{ }^{1} \mathrm{H}$ NMR (DMSO- $\left.d_{6}\right) ; \delta$ 6.64-6.65 (m, 1H), 6.87 (d, J=3.1 Hz, 1H), 6.95 (d, J=3.8 Hz, 1H), 7.41 (d, J=3.8 Hz, 1H), 7.71-7.85 (m, 4H), 9.43 (br s, 4H, exchangeable with $\mathrm{D}_{2} \mathrm{O}$ ). MS (EI) m/e (rel int); $270\left(\mathrm{M}^{+}, 100\right), 271\left(\mathrm{M}^{+}+1,19\right), 254$ (42). Anal Calcd for $\mathrm{C}_{15} \mathrm{H}_{11} \mathrm{FN}_{2} \mathrm{O}_{2}-1.0 \mathrm{HCl}$ : C 58.73; H 3.94; N 9.13. Found: C 58.45; H 4.21; N 8.93.

\section{3-Fluoro-4-(5-(thiophen-2-yl)furan-2-yl)benzamidine hydrochloride salt (5c)}

A yellow solid in $72 \%$ yield, mp $282^{\circ} \mathrm{C}-284^{\circ} \mathrm{C}(\mathrm{EtOH} /$ $\left.\mathrm{H}_{2} \mathrm{O}\right)$. IR ( $\left.\mathrm{KBr}\right)$ v' 3335, $3246\left(\mathrm{NH}, \mathrm{NH}_{2}\right), 3131,3059(\mathrm{CH})$, 1679, 1619, $1598(\mathrm{C}=\mathrm{N}, \mathrm{NH}$ bending, $\mathrm{C}=\mathrm{C}) \mathrm{cm}^{-1} .{ }^{1} \mathrm{H} \mathrm{NMR}$ $\left(\mathrm{DMSO}-d_{6}\right) ; \delta 7.03(\mathrm{~d}, \mathrm{~J}=3.3 \mathrm{~Hz}, 1 \mathrm{H}), 7.18-7.21(\mathrm{~m}, 2 \mathrm{H})$, 7.61-7.67 (m, 2H), 7.82-7.93 (m, 2H), 8.08 (t, J=7.8 Hz, $1 \mathrm{H}), 9.42$ (br s, $4 \mathrm{H}$, exchangeable with $\mathrm{D}_{2} \mathrm{O}$ ). MS (EI) m/e (rel int); $286\left(\mathrm{M}^{+}, 100\right), 287\left(\mathrm{M}^{+}+1,19\right), 270$ (31), 269 (15). Anal Calcd for $\mathrm{C}_{15} \mathrm{H}_{11} \mathrm{FN}_{2} \mathrm{OS}-1.0 \mathrm{HCl}-0.75 \mathrm{H}_{2} \mathrm{O}$ : C 53.57; H 4.04; N 8.32. Found: C 53.63; H 4.18; N 7.99.

\section{2-Fluoro-4-(5-(thiophen-2-yl)furan-2-yl)benzamidine hydrochloride salt $(5 d)$}

A yellow solid in $52 \%$ yield, mp $268^{\circ} \mathrm{C}-269.5^{\circ} \mathrm{C}(\mathrm{EtOH} /$ $\left.\mathrm{H}_{2} \mathrm{O}\right)$. IR (KBr) v’3296, $3185\left(\mathrm{NH}, \mathrm{NH}_{2}\right), 3111,3033$ $(\mathrm{CH}), 1662,1622(\mathrm{C}=\mathrm{N}, \mathrm{NH}$ bending, $\mathrm{C}=\mathrm{C}) \mathrm{cm}^{-1}$. ${ }^{1} \mathrm{H}$ NMR (DMSO- $\left.d_{6}\right) ; \delta 6.98(\mathrm{~d}, \mathrm{~J}=3.3 \mathrm{~Hz}, 1 \mathrm{H}), 7.17-7.20$ $(\mathrm{m}, 1 \mathrm{H}), 7.42(\mathrm{~d}, \mathrm{~J}=3.6 \mathrm{~Hz}, 1 \mathrm{H}), 7.59-7.65(\mathrm{~m}, 2 \mathrm{H})$, 7.76-7.82 (m, 3H), 9.36 (br s, $2 \mathrm{H}$, exchangeable with $\mathrm{D}_{2} \mathrm{O}$ ), 9.49 (br s, 2H, exchangeable with $\mathrm{D}_{2} \mathrm{O}$ ). $\mathrm{MS}$ (EI) m/e (rel int); $286\left(\mathrm{M}^{+}, 100\right), 287\left(\mathrm{M}^{+}+1,20\right), 270$ (53), 269 (16). Anal Calcd for $\mathrm{C}_{15} \mathrm{H}_{11} \mathrm{FN}_{2} \mathrm{OS}-1.0 \mathrm{HCl}-0.5 \mathrm{H}_{2} \mathrm{O}$ : C 54.30; H 3.95; N 8.44. Found: C 54.34; H 3.97; N 8.49.

\section{4-(2,2'-Bithiophen-5-yl)-2-fluorobenamidine \\ hydrochloride salt (5e)}

A yellowish-brown solid in $73 \%$ yield, mp $289^{\circ} \mathrm{C}-291^{\circ} \mathrm{C}$ (EtOH/H $\left.\mathrm{H}_{2} \mathrm{O}\right)$. IR (KBr) v' 3298, 3197 (NH, $\left.\mathrm{NH}_{2}\right), 3098$, $3018(\mathrm{CH}), 1656,1620(\mathrm{C}=\mathrm{N}, \mathrm{NH}$ bending, $\mathrm{C}=\mathrm{C}) \mathrm{cm}^{-1}$. ${ }^{1} \mathrm{H}$ NMR (DMSO- $\left.d_{6}\right) ; \delta$ 7.10-7.11 $(\mathrm{m}, 1 \mathrm{H}), 7.39(\mathrm{~s}, 2 \mathrm{H})$, 7.57 (d, J=4.2 Hz, 1H), 7.65-7.84 (m, 4H), 9.50 (br s, 4H, exchangeable with $\left.\mathrm{D}_{2} \mathrm{O}\right)$. MS (EI) m/e (rel int); $302\left(\mathrm{M}^{+}\right.$, 100), 286 (42). Anal Calcd for $\mathrm{C}_{15} \mathrm{H}_{11} \mathrm{FN}_{2} \mathrm{~S}_{2}-1.0 \mathrm{HCl}$ : C 53.17; H 3.57; N 8.27. Found: C 52.86; H 3.61; N 8.44.

\section{Biology}

The Salmonella typhimurium TA1535 bacterial strain was obtained from American Type Culture Collection (ATCC, Manassas, VA, USA). $\mathrm{NaN}_{3}, \mathrm{~B}[\mathrm{a}] \mathrm{P}$, and nicotinamide adenine dinucleotide phosphate reduced (NADPH) were obtained from Sigma-Aldrich (St Louis, MO, USA). The S9 mix was prepared as described elsewhere. ${ }^{8}$

\section{Cytotoxicity assays}

The effect of fluoroarylbichalcophenes on the viability of S. typhimurium TA1535 was investigated by growing the bacteria under two exposure conditions: broth microdilution and colony plate counting methods. The details have been described elsewhere. ${ }^{8}$

\section{Combined cytotoxic effect of fluoroaryl-2,2'- bichalcophenes and selected mutagens}

Prior to mutagenicity/antimutagenicity assay evaluation, exclusion of the possible toxic effect that could arise from the combination of mutagens used with fluoroarylbichalcophenes was performed. Cytotoxicity assays were performed as previously mentioned, with some modifications as previously described elsewhere. ${ }^{8}$

\section{Mutagenicity/antimutagenicity assays}

The potential mutagenic activity of the fluoroarylbichalcophenes was assayed according to Maron and Ames ${ }^{14}$ and fully described elsewhere. ${ }^{8}$ To assess the antimutagenic potential of fluoroarylbichalcophenes toward $\mathrm{NaN}_{3}$ or $\mathrm{B}[\mathrm{a}] \mathrm{P}$, preexposure and co-exposure assays were carried out simultane- 
ously via a method modified from Maron and Ames. ${ }^{14}$ Under pre-exposure conditions, each fluoroarylbichalcophene was incubated with $S$. typhimurium TA 1535 at $37^{\circ} \mathrm{C}$ for $30 \mathrm{~min}-$ utes on shaking incubator before the addition of the mutagen. Co-exposure assays were performed by incubating the bacteria, the mutagen, and each fluoroarylbichalcophene at $37^{\circ} \mathrm{C}$ for 30 minutes prior to plating on minimal glucose agar (MGA). Positive and negative controls were performed in all assays. All antimutagenesis determinations were performed in triplicate. The number of revertant colonies was counted after 48 hours of incubation, and the antimutagenic potential of the tested compounds was expressed as a percentage of reduction in mutagenicity, ${ }^{16}$ and calculated according to the following equation:

$\%$ reduction in mutagenicity $=([\mathrm{Rm}-\mathrm{Rs}]-[\mathrm{Ra}-\mathrm{Rs}] /$

$$
[\mathrm{Rm}-\mathrm{Rs}]) \times 100
$$

where $\mathrm{Rm}$ is the number of revertants/plate in the presence of mutagen, Rs is the number of spontaneous revertants/plate, and $\mathrm{Ra}$ is the number of revertants/plate in the presence of fluoroarylbichalcophenes.

A $20 \%$ or less reduction means no antimutagenic activity, $20 \%-40 \%$ reduction means moderate activity, and $40 \%$ or more reduction means strong antimutagenic activity.

The mutant frequency or mutation rate was then calculated from the mutant colonies/viable colonies for both exposure conditions for the mutagens investigated. All procedures were approved by the University of King Faisal Committee of Scientific Research Ethics.

\section{Determination of total antioxidant activity}

The antioxidant activity of fluoroarylbichalcophenes was measured spectrophotometrically using a phosphomolybdenum method, ${ }^{17}$ based on the reduction of $\mathrm{Mo}(\mathrm{VI})$ to $\mathrm{Mo}(\mathrm{V})$ and the subsequent formation of specific green phosphate/Mo(V) compounds. A $0.3 \mathrm{~mL}$ aliquot of sample solution $(20 \mu \mathrm{M}$ final concentration) was combined with $2.7 \mathrm{~mL}$ of the reagent solution ( $0.6 \mathrm{M}$ sulfuric acid, $28 \mathrm{mM}$ sodium phosphate, and $4 \mathrm{mM}$ ammonium molybdate). The sample was capped and incubated in a boiling water bath at $95^{\circ} \mathrm{C}$ for 90 minutes. After cooling to room temperature, the absorbance was measured at $695 \mathrm{~nm}$. Stock solution of ascorbate was freshly prepared and used as a standard antioxidant.

\section{Statistical analysis of data}

Statistical analyses of data were performed using analysis of variance (ANOVA), followed by Fisher's protected least significant difference multiple range test. Differences were considered significant at $P$-values of $<0.05$.

\section{Results and discussion Chemistry}

A series of bichalcophene fluorobenzamidines 5a-e was prepared from the corresponding mononitriles $4 \mathrm{a}-\mathrm{e}$ by direct reaction with $\mathrm{LiN}(\mathrm{TMS})_{2}$ (Figure 2). Thus, compound 4-(2,2'-bifuran-5-yl)-3-fluorobenzamidine (5a) was obtained from the corresponding mononitrile $4 \mathrm{a}$ by treatment with $\mathrm{LiN}(\mathrm{TMS})_{2}$ followed by deprotection with ethanolic $\mathrm{HCl}$ (gas). The structures of fluorobenzamidines 5a-e were identified by their spectroscopic and elemental analyses. Thus, ${ }^{1} \mathrm{H}$ NMR spectrum of compound 5a displayed singlet signal at $\delta 9.44(4 \mathrm{H})$ characteristic for the cationic amidine group in addition to the signals corresponding to the trisubstituted benzene ring and bifuran moiety. Fluoroarylbichalcophene mononitriles $4 \mathrm{a}-\mathrm{e}$ were prepared adopting a Stille coupling reaction between the corresponding bromo compounds $3 \mathrm{a}-\mathrm{c}$ and 2-(tri- $n$-butylstannyl)furan or analogues using our previously described methodology for the preparation of non-fluorinated bichalcophene analogues. ${ }^{18}$ The structures of compounds $4 \mathrm{a}-\mathrm{e}$ were assigned based on their spectral and elemental analyses.

\section{Biology Cytotoxicity}

Investigating novel compounds for therapeutic and pharmacological activities should be parallel with omitting their toxicological effects. In addition, the determination of the potential mutagenic effect of any drug under development is mandatory. In our previous studies, ten novel bichalcophenes showed no genotoxic effects and were effective in reducing the mutagenicity induced by $\mathrm{NaN}_{3}$ and $\mathrm{B}[\mathrm{a}] \mathrm{P}$ in the Ames microsomal assay. ${ }^{8}$ A series of fluoroarylbichalcophene derivatives was synthesized and examined for their antimutagenic potency. To rule out the possible toxic effect exerted by the investigated fluoroarylbichalcophenes on the viability of $S$. typhimurium TA1535, the non-toxic/non-growth inhibitory concentrations were determined by growing the bacteria under two exposure conditions: broth microdilution and colony plate counting methods. In the broth microdilution method, all fluoroarylbichalcophenes caused a significant reduction in the viability of S. typhimurium TA1535 at 50 and $100 \mu \mathrm{M}$ as compared with control untreated cells (Table 1). No significant toxicity was reported with all compounds at $25 \mu \mathrm{M}$. The effect of fluoroarylbichalcophenes on the total viable count of TA1535 was performed at 10 and $20 \mu \mathrm{M}$ to avoid any toxicity concerns that may 
<smiles>[R]c1c(Br)ccc(C#N)c1[R]</smiles><smiles>[R]Cc1[X]c(-c2ccc(C#N)c([R])c2[R])cc1</smiles>

;<smiles></smiles>

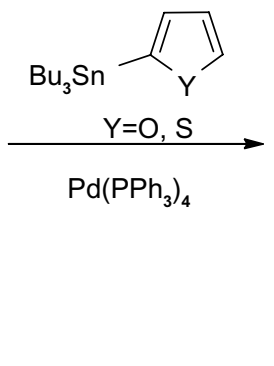<smiles>[R]c1c(C#N)ccc(-c2[X]c(-c3ccc[Y]3[H])cc2)c1[R]</smiles><smiles>[R][X]1c(-c2ccc[Y]2[H])ccc1-c1ccc(C(=N)N)c([R])c1[R]</smiles>

$\begin{array}{rllll}\text { Code: } \mathbf{4 , 5} & \mathbf{R}_{1} & \mathbf{R}_{\mathbf{2}} & \mathbf{X} & \mathbf{Y} \\ \text { a; } & \text { F } & \text { H } & \text { O } & \text { O } \\ \text { b; } & \text { H } & \text { F } & \text { O } & \text { O } \\ \text { c; } & \text { F } & \text { H } & \text { O } & \text { S } \\ \text { d; } & \text { H } & \text { F } & \text { O } & \text { S } \\ \text { e; } & \text { H } & \text { F } & \text { S } & \text { S }\end{array}$

Figure 2 Synthesis of novel monocationic fluoroaryl-2,2'-bichalcophene derivatives.

Table I Cytotoxicity of fluoroarylbichalcophenes to Salmonella typhimurium TAI535 in liquid medium

\begin{tabular}{lccr}
\hline Compound & \multicolumn{3}{l}{$\begin{array}{l}\text { Viability at fluoroarylbichalcophene } \\
\text { concentrations (\% of control) }\end{array}$} \\
\cline { 2 - 4 } & $\mathbf{2 5 \mu M}$ & $\mathbf{5 0 \mu M}$ & $100 \mu \mathbf{M}$ \\
\hline $4 \mathrm{a}$ & $100.0 \pm 8.5$ & $66.3 \pm 5.6^{\mathrm{a}}$ & $45.7 \pm 3.5^{\mathrm{a}}$ \\
$4 \mathrm{~b}$ & $88.3 \pm 7.4$ & $64.7 \pm 6.6^{\mathrm{a}}$ & $29.0 \pm 3.1^{\mathrm{a}}$ \\
$4 \mathrm{c}$ & $104.7 \pm 11.6$ & $61.0 \pm 7.0^{\mathrm{a}}$ & $2.7 \pm 0.4^{\mathrm{a}}$ \\
$4 \mathrm{~d}$ & $71.7 \pm 5.0$ & $59.7 \pm 4.7^{\mathrm{a}}$ & $3.0 \pm 0.2^{\mathrm{a}}$ \\
$4 \mathrm{e}$ & $104.0 \pm 9.9$ & $64.7 \pm 8.1^{\mathrm{a}}$ & $22.3 \pm 2.2^{\mathrm{a}}$ \\
$5 \mathrm{a}$ & $102.3 \pm 10.2$ & $63.3 \pm 9.0^{\mathrm{a}}$ & $32.7 \pm 2.7^{\mathrm{a}}$ \\
$5 \mathrm{~b}$ & $101.7 \pm 11.3$ & $62.0 \pm 5.5^{\mathrm{a}}$ & $36.7 \pm 2.8^{\mathrm{a}}$ \\
$5 \mathrm{c}$ & $71.3 \pm 6.4$ & $58.7 \pm 4.2^{\mathrm{a}}$ & $28.7 \pm 3.0^{\mathrm{a}}$ \\
$5 \mathrm{~d}$ & $105.7 \pm 4.6$ & $65.3 \pm 3.9^{\mathrm{a}}$ & $49.3 \pm 3.8^{\mathrm{a}}$ \\
$5 \mathrm{e}$ & $73.7 \pm 4.1$ & $48.0 \pm 3.8^{\mathrm{a}}$ & $15.0 \pm 1.4^{\mathrm{a}}$ \\
\hline
\end{tabular}

Notes: ${ }^{2}$ Significantly different $(P<0.05)$ from bacteria grown in the absence of fluoroarylbichalcophenes. The cytotoxicity assays were performed in triplicate and are expressed as \% control (mean \pm SEM).

Abbreviation: SEM, standard error of the mean. arise with higher concentrations. All fluoroarylbichalcophenes were non-toxic and had no significant reducing effect on the total viable count of S. typhimurium TA1535 at both concentrations investigated. In a previous study on non-fluorinated bichalcophenes, ${ }^{8}$ compounds that correspond to compounds 5a and 5e in the current study were toxic at $25 \mu \mathrm{M}$ to Salmonella in liquid medium. The addition of a fluorine atom reduced the toxicity of these compounds (Table 1). This allowed the examination of the antimutagenic activity of these compounds at the highest concentration possible without compromising the bacterial growth due to toxicity effect.

\section{Effect of combination of fluoroarylbichalcophenes and mutagens on Salmonella typhimurium TAI 535 viability}

The combined toxic effect of the investigated compounds along with two selected mutagens was investigated to validate 
Table 2 Determination of mutagenic activity of fluoroaryl-2,2' bichalcophenes in Salmonella typhimurium TAI535 in presence of $\mathrm{S} 9 \mathrm{mix}$

\begin{tabular}{lcc}
\hline Compound & \multicolumn{2}{l}{$\begin{array}{l}\text { Fluoroarylbichalcophene } \\
\text { mutagenicity (revertant } \\
\text { colonies/plate; mean } \pm \text { SEM) }\end{array}$} \\
\cline { 2 - 3 } & $\mathbf{1 0 \mu \mathbf { M }}$ & $\mathbf{2 0 \mu \mathbf { M }}$ \\
\hline None (spontaneous) & $67.0 \pm 6.1$ & \\
B[a]P $(20 \mu \mathrm{M})$ & $327.7 \pm 23.5^{\mathrm{a}}$ & $69.7 \pm 7.0$ \\
4a & $63.3 \pm 5.5$ & $71.3 \pm 4.0$ \\
4b & $64.3 \pm 4.0$ & $68.7 \pm 5.5$ \\
4c & $65.3 \pm 5.4$ & $67.7 \pm 6.1$ \\
4d & $68.7 \pm 6.0$ & $66.7 \pm 6.7$ \\
4e & $65.3 \pm 6.2$ & $65.7 \pm 5.8$ \\
5a & $61.0 \pm 4.8$ & $65.0 \pm 4.9$ \\
5b & $68.7 \pm 4.0$ & $66.0 \pm 3.5$ \\
5c & $70.0 \pm 5.9$ & $67.7 \pm 6.0$ \\
5d & $65.0 \pm 7.0$ & $70.0 \pm 6.1$ \\
5e & $71.0 \pm 7.5$ &
\end{tabular}

Notes: aSignificantly different $(P<0.05)$ from non-treated bacteria (spontaneous mutations). Assays were performed in triplicate.

Abbreviations: $\mathrm{B}[\mathrm{a}] \mathrm{P}$, benzo[a]pyrene; SEM, standard error of the mean.

the antimutagenic assays and to ensure that the reduction in the number of revertant colonies was not related to any overt toxicity. A direct-acting mutagen $\left(\mathrm{NaN}_{3} ; 2 \mu \mathrm{g} / \mathrm{plate}\right)$ and a polycyclic aromatic indirect hydrocarbon mutagen $(\mathrm{B}[\mathrm{a}] \mathrm{P}$; $20 \mu \mathrm{M}$ ) were selected for this purpose. Both mutagens mutate S. typhimurium TA1535 with base-pair substitution mutation through different pathways. $\mathrm{NaN}_{3}$ does not require metabolic activation; however, B[a]P mutates TA1535 in the presence of rat liver microsomal enzymes (S9 fraction). The majority of mutations induced by $\mathrm{B}[\mathrm{a}] \mathrm{P}$ in various systems is at guanine, with most of the mutations being GC to TA transversions. ${ }^{19}$ None of the investigated fluoroarylbichalcophenes had a significant toxic effect on the viability of TA1535 when used along with $\mathrm{NaN}_{3}$ or $\mathrm{B}[\mathrm{a}] \mathrm{P}$ (data not shown).

\section{The mutagenic/antimutagenic potential of fluoroarylbichalcophenes against $\mathrm{NaN}_{3}$ and $\mathrm{B}[\mathrm{a}] \mathrm{P}$}

A gene mutation is a permanent DNA sequence change, and the accumulation of genetic errors results in cancer development. The Ames test was developed for the screening of chemical mutagenicity/carcinogenicity. The test is useful in detecting frame shift mutation or base substitution of DNA. ${ }^{20}$ This assay is very competent in screening for anticancer activity of novel compounds. This assay also enables the screening of a large number of compounds within a reasonable time frame and cost and helps identify the potential anticancer hits. On investigating the mutagenic effect of fluoroaryl compounds at non-growth inhibitory and nontoxic concentrations, all compounds were non-mutagenic to TA1535 in the presence or absence of S9 as compared with negative spontaneous revertant or positive control bacteria treated with $\mathrm{B}[\mathrm{a}] \mathrm{P}$ (Table 2). The assay was performed in the absence of S9 mix, and similar results were obtained (data not shown). The potential antimutagenic activity of fluoroaryl derivatives was evaluated using a modified Ames assay under pre-exposure and co-exposure treatments. Almost all fluoroarylbichalcophenes exerted a strong antimutagenic activity $(>40 \%)$ against $\mathrm{NaN}_{3}$-induced mutagenicity in pre-exposure

Table 3 Determination of antimutagenic activity of fluoroaryl-2,2'-bichalcophenes in Salmonella typhimurium TAI535 against sodium azide $(2 \mu g /$ plate $)$

\begin{tabular}{|c|c|c|c|c|}
\hline \multirow[t]{3}{*}{ Compound } & \multicolumn{4}{|c|}{$\begin{array}{l}\mathrm{NaN}_{3} \text { mutagenicity at fluoroarylbichalcophene concentrations (revertant colonies/plate; mean } \pm \text { SEM } \\
{\left[\% \text { reduction in } \mathrm{NaN}_{3} \text { mutagenicity]) }\right.}\end{array}$} \\
\hline & \multicolumn{2}{|l|}{ Pre-exposure } & \multicolumn{2}{|l|}{ Co-exposure } \\
\hline & $10 \mu \mathrm{M}$ & $20 \mu \mathrm{M}$ & $10 \mu \mathrm{M}$ & $20 \mu \mathrm{M}$ \\
\hline $\mathrm{NaN}_{3}$ & $137.7 \pm 7.0(0)$ & & & \\
\hline $4 a$ & $47.7 \pm 6.5(83)^{\mathrm{a}}$ & $26.0 \pm 5.5(103)^{\mathrm{a}}$ & $75.0 \pm 2.3(58)^{\mathrm{a}}$ & $34.3 \pm 4.9(95)^{\mathrm{a}, \mathrm{b}}$ \\
\hline $4 b$ & $69.7 \pm 8.0(62)^{\mathrm{a}, \mathrm{c}}$ & $48.3 \pm 5.0(82)^{\mathrm{a}}$ & $35.3 \pm 2.8(94)^{\mathrm{a}}$ & $32.7 \pm 5.5(97)^{\mathrm{a}}$ \\
\hline $4 c$ & $51.0 \pm 6.6(80)^{\mathrm{a}, \mathrm{c}}$ & $53.7 \pm 9.3(77)^{\mathrm{a}}$ & $44.7 \pm 6.0(86)^{\mathrm{a}, \mathrm{c}}$ & $40.0 \pm 5.0(90)^{a}$ \\
\hline $4 d$ & $36.0 \pm 2.7(94)^{\mathrm{a}, \mathrm{c}}$ & $29.7 \pm 4.0(100)^{\mathrm{a}}$ & $47.7 \pm 2.7(83)^{\mathrm{a}}$ & $49.7 \pm 6.4(8 I)^{a, c}$ \\
\hline $4 e$ & $24.7 \pm 3.5(104)^{\mathrm{a}, \mathrm{c}}$ & $21.7 \pm 2.1(107)^{\mathrm{a}}$ & $36.7 \pm 4.7(93)^{\mathrm{a}}$ & $25.0 \pm 5.6(104)^{\mathrm{a}}$ \\
\hline $5 a$ & $57.7 \pm I I .0(74)^{\mathrm{a}}$ & $22.3 \pm 2.1(106)^{a, b}$ & $73.3 \pm 4.1(59)^{\mathrm{a}}$ & $39.0 \pm 8.1(91)^{\mathrm{a}, \mathrm{b}}$ \\
\hline $5 b$ & $|26.7 \pm| \mid .2(10)$ & $40.3 \pm 6.5(90)^{\mathrm{a}, \mathrm{b}}$ & $26.0 \pm 2.0(103)^{\mathrm{a}}$ & $21.7 \pm 2.5(107)^{\mathrm{a}}$ \\
\hline $5 c$ & $102.0 \pm 7.2(32)^{\mathrm{a}}$ & $33.3 \pm 8.7(96)^{a, b}$ & $25.7 \pm 1.8(103)^{\mathrm{a}}$ & $24.0 \pm 3.0(105)^{\mathrm{a}}$ \\
\hline $5 d$ & $65.0 \pm 5.0(67)^{\mathrm{a}}$ & $44.3 \pm 4.5(86)^{a, b}$ & $43.3 \pm 6.8(87)^{\mathrm{a}}$ & $20.0 \pm 1.0(109)^{\mathrm{a}, \mathrm{b}}$ \\
\hline $5 e$ & $47.7 \pm 6.2(83)^{\mathrm{a}}$ & $18.0 \pm 3.6(|| \mid 0)^{\mathrm{a}, \mathrm{b}}$ & $24.7 \pm 2.6(104)^{a}$ & $21.0 \pm 1.0(108)^{\mathrm{a}}$ \\
\hline
\end{tabular}

Notes: asignificant $(P<0.05)$ reduction (\% of inhibition of mutagenicity indicated in parentheses) from revertant colonies seen with $\mathrm{NaN}_{3}$, $40 \%$ or more reduction means strong antimutagenic activity; 'bignificant difference $(P<0.05)$ between fluoroarylbichalcophene concentrations; 'significant difference $(P<0.05)$ between mononitrile compounds $(4 \mathrm{a}-4 \mathrm{e})$ versus corresponding monocationic compounds $(5 \mathrm{a}-5 \mathrm{e})$. Assays were performed in triplicate. The spontaneous revertant colonies were $29.3 \pm 5.3$. Abbreviations: $\mathrm{NaN}_{3}$, sodium azide; SEM, standard error of the mean. 
Table 4 Determination of antimutagenic activity of fluoroaryl-2,2'-bichalcophenes in Salmonella typhimurium TAI535 against benzo[a] pyrene $20 \mu \mathrm{M}$ in the presence of 59 mix

\begin{tabular}{|c|c|c|c|c|}
\hline \multirow[t]{3}{*}{ Compound } & \multicolumn{4}{|c|}{$\begin{array}{l}\mathrm{B}[\mathrm{a}] \mathrm{P} \text { mutagenicity at fluoroarylbichalcophene concentrations (revertant colonies/plate; mean } \pm \mathrm{SEM} \\
{[\% \text { reduction in B }[\mathrm{a}] \mathrm{P} \text { mutagenicity }] \text { ) }}\end{array}$} \\
\hline & \multicolumn{2}{|l|}{ Pre-exposure } & \multicolumn{2}{|l|}{ Co-exposure } \\
\hline & $10 \mu \mathrm{M}$ & $20 \mu \mathrm{M}$ & $10 \mu \mathrm{M}$ & $20 \mu \mathrm{M}$ \\
\hline $\mathrm{B}[\mathrm{a}] \mathrm{P}$ & $319.0 \pm 21.3(0)$ & & & \\
\hline $4 a$ & $267.0 \pm I I .0(24)^{\mathrm{a}, \mathrm{c}}$ & $267.7 \pm 13.0(24)^{\mathrm{a}, \mathrm{c}}$ & $270.0 \pm 19.0(23)^{\mathrm{a}, \mathrm{c}}$ & $268.0 \pm 16.6(24)^{a, c}$ \\
\hline $4 b$ & $239.3 \pm 10.5(37)^{\mathrm{a}, \mathrm{c}}$ & $238.0 \pm 7.6(38)^{a, c}$ & $193.0 \pm 15.7(59)^{\mathrm{a}}$ & $154.7 \pm 16.5(77)^{\mathrm{a}}$ \\
\hline $4 c$ & $|77.0 \pm| \mid .3(66)^{\mathrm{a}}$ & $153.7 \pm 7.0(77)^{\mathrm{a}, \mathrm{c}}$ & $279.3 \pm 19.5(19)^{c}$ & $269.3 \pm 9.0(23)^{\mathrm{a}, \mathrm{c}}$ \\
\hline $4 d$ & $271.0 \pm 16.5(22)^{\mathrm{a}}$ & $271.0 \pm 12.2(22)^{\mathrm{a}, \mathrm{c}}$ & $287.7 \pm 16.0(15)^{c}$ & $204.0 \pm 5.3(54)^{\mathrm{a}-\mathrm{c}}$ \\
\hline $4 e$ & $241.3 \pm 11.0(36)^{\mathrm{a}}$ & $201.0 \pm 10.5(55)^{a, c}$ & $282.3 \pm 16.6(17)^{c}$ & $285.0 \pm 18.1(16)^{\mathrm{a}, \mathrm{c}}$ \\
\hline $5 a$ & $209.7 \pm 10.3(51)^{\mathrm{a}}$ & $201.0 \pm$ II.0 (55) & $102.0 \pm 12.1(101)^{a}$ & $98.3 \pm 9.5(103)^{\mathrm{a}}$ \\
\hline $5 b$ & $178.0 \pm 8.2(66)^{\mathrm{a}}$ & $163.0 \pm 7.9(73)^{\mathrm{a}}$ & $213.7 \pm 15.8(49)^{\mathrm{a}}$ & $166.0 \pm 6.6(7 \mid)^{a, b}$ \\
\hline $5 c$ & | $48.7 \pm 9.8(80)^{\mathrm{a}}$ & $124.0 \pm 5.3(9 \mid)^{\mathrm{a}}$ & $110.7 \pm 10.5(97)^{\mathrm{a}}$ & $111.0 \pm 10.2(97)^{\mathrm{a}}$ \\
\hline $5 d$ & $261.0 \pm 8.5(27)^{\mathrm{a}}$ & $216.7 \pm 14.3(48)^{\mathrm{a}}$ & $109.7 \pm 8.3(98)^{a}$ & $101.0 \pm 6.0(102)^{\mathrm{a}}$ \\
\hline $5 e$ & $274.3 \pm 12.5(21)^{\mathrm{a}}$ & $273.3 \pm 10.8(21)^{\mathrm{a}}$ & $101.0 \pm 11.0(102)^{\mathrm{a}}$ & $98.0 \pm 6.1(103)^{\mathrm{a}}$ \\
\hline
\end{tabular}

Notes: aSignificant $(P<0.05)$ reduction $(\%$ of inhibition of mutagenicity indicated in parentheses) from revertant colonies seen with $B[a] P, 20 \%$ or less means no activity, $20 \%-40 \%$ indicates moderate activity, and $40 \%$ or more reduction means strong antimutagenic activity; ${ }^{b}$ significant difference $(P<0.05)$ between fluoroarylbichalcophene concentrations; 'significant difference $(P<0.05)$ between mononitrile compounds $(4 \mathrm{a}-4 \mathrm{e})$ versus corresponding monocationic compounds $(5 \mathrm{a}-5 \mathrm{e})$. Assays were performed in triplicate. The spontaneous revertant colonies were 105.0 I 3.I.

Abbreviations: $\mathrm{B}[\mathrm{a}] \mathrm{P}$, benzo[a]pyrene; SEM, standard error of the mean.

and co-exposure assays (Table 3). Under the pre-exposure condition, the investigated compounds were antimutagenic at 10 and $20 \mu \mathrm{M}$ except for compound $5 \mathrm{~b}$ and $5 \mathrm{c}$, which exerted a strong antimutagenic potential only at $20 \mu \mathrm{M}$. The recorded antimutagenic activity was concentrationdependent with monocationic fluoroaryl derivatives (5a-5e) under pre-exposure conditions. However, the difference in concentration had no significant effect on the recorded activity in co-exposure experiments, except with derivatives $5 \mathrm{a}$ and $5 \mathrm{~d}$ (Table 3 ). In terms of the difference between mononitrile and the corresponding monocationic, mononitrile

Table 5 Effects of fluoroaryl-2,2'-bichalcophenes on sodium azide mutant frequency

\begin{tabular}{|c|c|c|c|c|}
\hline \multirow[t]{3}{*}{ Compound } & \multicolumn{4}{|c|}{ Mutant frequency and $\left(\% \text { of } \mathrm{NaN}_{3}\right)^{a}$} \\
\hline & \multicolumn{2}{|c|}{ Pre-exposure } & \multicolumn{2}{|c|}{ Co-exposure } \\
\hline & $10 \mu \mathrm{M}$ & $20 \mu \mathrm{M}$ & $10 \mu \mathrm{M}$ & $20 \mu \mathrm{M}$ \\
\hline $\mathrm{NaN}_{3}$ & $2.65(100)$ & & & \\
\hline $4 a^{3}$ & $0.99(37)^{b}$ & $0.52(20)^{\mathrm{b}}$ & $\mathrm{I} .55(59)^{\mathrm{b}}$ & $0.69(26)^{b}$ \\
\hline $4 b$ & $1.28(48)^{b}$ & $0.95(36)^{b}$ & $0.65(25)^{\mathrm{b}}$ & $0.64(24)^{b}$ \\
\hline $4 c$ & $0.93(35)^{b}$ & $\mathrm{I} .05(40)^{\mathrm{b}}$ & $0.8 \mathrm{I}(3 \mathrm{I})^{\mathrm{b}}$ & $0.78(29)^{\mathrm{b}}$ \\
\hline $4 d$ & $0.69(26)^{\mathrm{b}}$ & $0.56(2 \mathrm{l})^{\mathrm{b}}$ & $0.92(35)^{\mathrm{b}}$ & $0.94(35)^{\mathrm{b}}$ \\
\hline $4 e$ & $0.44(17)^{b}$ & $0.42(16)^{b}$ & $0.66(25)^{b}$ & $0.48(18)^{b}$ \\
\hline $5 a$ & $1.03(39)^{b}$ & $0.44(17)^{\mathrm{b}}$ & $\mathrm{I} .3 \mathrm{I}(49)^{\mathrm{b}}$ & $0.76(29)^{\mathrm{b}}$ \\
\hline $5 b$ & $2.45(92)$ & $0.79(30)^{b}$ & $0.50(19)^{b}$ & $0.43(16)^{b}$ \\
\hline $5 c$ & $1.91(72)$ & $0.65(24)^{b}$ & $0.48(18)^{\mathrm{b}}$ & $0.47(18)^{b}$ \\
\hline $5 d$ & I. $14(43)^{\mathrm{b}}$ & $0.88(33)^{b}$ & $0.76(29)^{\mathrm{b}}$ & $0.40(15)^{b}$ \\
\hline $5 e$ & $0.84(32)^{b}$ & $0.35(13)^{\mathrm{b}}$ & $0.48(18)^{b}$ & $0.4 \mathrm{I}(16)^{\mathrm{b}}$ \\
\hline
\end{tabular}

Notes: ${ }^{2}$ Calculated from mutant colonies (Table 3)/viable colonies; ${ }^{b}$ significant $(P<0.05)$ reduction from mutant frequency seen with $\mathrm{NaN}_{3}$.

Abbreviation: $\mathrm{NaN}_{3}$, sodium azide. derivatives $(4 \mathrm{~b}-4 \mathrm{e})$ were more active than the corresponding monocationic derivatives under pre-exposure treatment at the low concentration investigated. For much similar bichalcophenes, the monocationic derivatives were more effective than the corresponding mononitrile derivatives. ${ }^{8}$ This rule still stands in the present study but was contradicted once at the low concentration and under the pre-exposure conditions against azide-mutagenicity (Table 3). A similar trend of inhibition of mutagenicity against $\mathrm{B}[\mathrm{a}] \mathrm{P}$ was also recorded. When evaluating the antimutagenic potency of fluoroarylbichalcophenes against $\mathrm{B}[\mathrm{a}] \mathrm{P}-$-induced mutagenicity, all compounds caused

Table 6 Effects of fluoroaryl-2,2'-bichalcophenes on benzo[a] pyrene mutant frequency

\begin{tabular}{|c|c|c|c|c|}
\hline \multirow[t]{3}{*}{ Compound } & \multicolumn{4}{|c|}{ Mutant frequency $(\% \text { of } B[a] P)^{a}$} \\
\hline & \multicolumn{2}{|c|}{ Pre-exposure } & \multicolumn{2}{|c|}{ Co-exposure } \\
\hline & $10 \mu \mathrm{M}$ & $20 \mu \mathbf{M}$ & $10 \mu \mathrm{M}$ & $20 \mu \mathrm{M}$ \\
\hline $\mathrm{B}[\mathrm{a}] \mathrm{P}$ & $4.89(100)$ & & & \\
\hline $4 a$ & $4.04(83)$ & $4.14(85)$ & $4.08(84)$ & $4.14(85)$ \\
\hline $4 \mathrm{~b}$ & $3.72(76)$ & $3.70(76)$ & $3.00(6 I)^{b}$ & $2.4 I(49)^{b}$ \\
\hline $4 c$ & $2.8 \mathrm{I}(57)^{\mathrm{b}}$ & $2.52(52)^{b}$ & $4.43(91)$ & $4.4 I(90)$ \\
\hline $4 d$ & $4.12(84)$ & $4.37(89)$ & $4.38(90)$ & $3.29(67)^{\mathrm{b}}$ \\
\hline $4 e$ & $3.66(75)$ & $3.09(63)^{b}$ & $4.28(87)$ & $4.38(90)$ \\
\hline $5 a$ & $3.26(67)^{b}$ & $3.37(69)^{b}$ & $1.59(32)^{b}$ & $1.65(34)^{b}$ \\
\hline $5 b$ & $2.8 \mathrm{I}(58)^{\mathrm{b}}$ & $2.53(52)^{b}$ & $3.38(69)^{b}$ & $2.58(53)^{b}$ \\
\hline $5 c$ & $2.23(46)^{b}$ & $2.02(4 I)^{b}$ & $1.66(34)^{\mathrm{b}}$ & $\mathrm{I} .8 \mathrm{I}(37)^{\mathrm{b}}$ \\
\hline $5 d$ & $4.19(86)$ & $3.28(67)^{\mathrm{b}}$ & $\mathrm{I} .76(36)^{\mathrm{b}}$ & $\mathrm{I} .53(3 \mathrm{I})^{\mathrm{b}}$ \\
\hline $5 e$ & $4.09(84)$ & $4.61(94)$ & $\mathrm{I} .5 \mathrm{I}(3 \mathrm{I})^{\mathrm{b}}$ & $\mathrm{I} .65(34)^{\mathrm{b}}$ \\
\hline
\end{tabular}

Notes: ${ }^{a}$ Calculated from mutant colonies (Table 4)/viable colonies; ${ }^{b}$ significant $(P<0.05)$ reduction from mutant frequency seen with $B[a] P$.

Abbreviation: $\mathrm{B}[\mathrm{a}] \mathrm{P}$, benzo[a]pyrene. 
a non-concentration-dependent reduction $(21 \%-91 \%)$ in the induced mutagenicity under the pre-exposure condition (Table 4). In the co-exposure experiment, all compounds showed a low to strong antimutagenic potential at 10 and $20 \mu \mathrm{M}$, except derivatives $4 \mathrm{c}$, 4d, and $4 \mathrm{e}$, which had no significant activity at the low concentration investigated. The investigated monocationic derivatives were more effective than the corresponding mononitrile in both pre- and co-treatment conditions. It seems that the bacteria were able to metabolize these fluorinated bichalcophenes much faster than the corresponding non-fluorinated bichalcophenes. This resulted in less efficiency in the antimutagenic activity of fluorinated compounds against $\mathrm{NaN}_{3}$-mutagenicity, especially at the low concentration (Table 3), ie, the metabolites were less active antimutagenic agents than the parent compounds. This hypothesis was also supported by the data from the co-exposure regimen where there was almost no difference between the fluorinated and non-fluorinated compounds. In this exposure regimen, the mutagen, bacteria, and the fluoroarylbichalcophenes were mixed at the same time. The fluorine substitution elevated the antimutagenic behavior of bichalcophenes against $\mathrm{B}[\mathrm{a}] \mathrm{P}$ mutagenicity. Fluorinated monocationic bichalcophenes showed a remarkable antimutagenic profile, reflecting the ability of these compounds to interfere with the cytochrome P450 (CYP450)-dependent activation of B[a]P (Table 4). The P450 system was blocked by many fluorinated compounds. ${ }^{12,21}$ $\mathrm{B}[\mathrm{a}] \mathrm{P}$ is known to be metabolized by CYP1A1/2 followed by epoxide hydrolysis; both steps were suppressed by fluorinesubstituted compounds..$^{22}$ In a previous study, ${ }^{10}$ there was an evident structural-activity relationship, where the activity was elevated by the presence of a thiophene ring. This phenomenon could not be discerned in the current study where the presence of thiophene ring(s) in compounds 4 and 5 (c-e) had sporadic effects on the antimutagenic activities of these compounds.

Mutation frequency is highly correlated to mutation rate. All fluoroarylbichalcophenes reduced the mutant frequency caused by $\mathrm{NaN}_{3}$ by $8 \%-87 \%$ (Table 5 ). Most of the monocationic compounds were more effective than the mononitrile compounds in reducing the mutant frequency under co-exposure conditions. With regard to the reduction of mutant frequency with $\mathrm{B}[\mathrm{a}] \mathrm{P}$, the investigated compounds were not as effective as they were against $\mathrm{NaN}_{3}$ and caused a reduction between $6 \%$ and $69 \%$ in the recorded mutant frequency (Table 6). The recorded antimutagenic activity of the investigated compounds could be attributed to various mechanisms. These compounds could interfere with the azide absorption into the bacteria by modifying the cell membrane or they could prevent the azide binding to DNA. Another mechanism is the direct binding and protection of DNA from the electrophilic mutagen or its metabolites, ${ }^{23}$ given that the fluoroaryl derivatives are nucleophilic. One of the possible mechanisms is the inhibition of CYP4501A activity that metabolically activates $\mathrm{B}[\mathrm{a}] \mathrm{P}$, based on the inhibition of enzymatic oxidation at the site of F-substitution due to its electron-withdrawing nature. ${ }^{13,24}$ Another possible mechanism could be the elevation in the antioxidant milieu of the cells, thus promoting the DNA repair system. ${ }^{25}$ Testing the total antioxidant activity of fluoroaryl

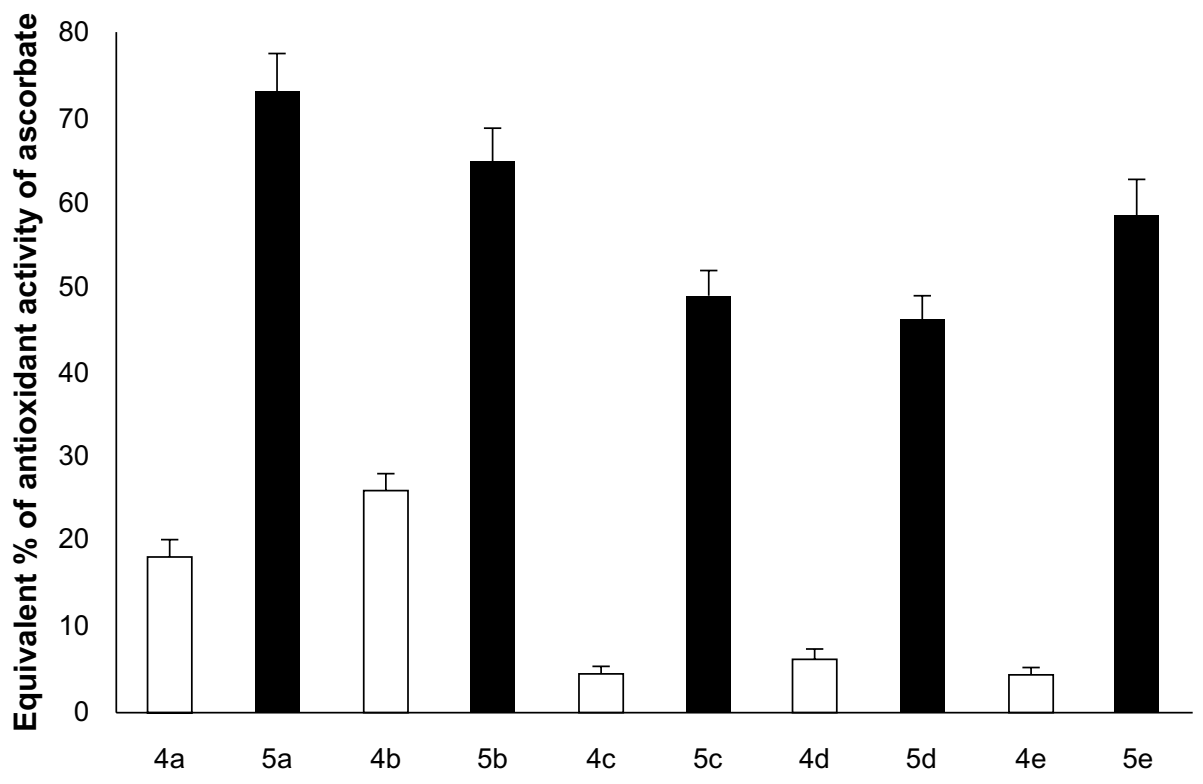

Figure 3 Total antioxidant activity of fluoroaryl-2,2'-bichalcophene derivatives at $25 \mu \mathrm{M}$ expressed as the percentage of equivalent ascorbate activity at the same concentration. Notes: $4 \mathrm{a}-4 \mathrm{e}$ are the mononitrile derivatives and $5 \mathrm{a}-5 \mathrm{e}$ are the corresponding monocationic derivatives. Assays were performed in triplicate. 
compounds showed that compounds $5 \mathrm{a}-\mathrm{e}$ were in the lead, with antioxidant activity of $\sim 46 \%-73 \%$ of that of ascorbic acid at the same concentration (Figure 3 ). The promising antioxidant activity could provide a protective effect of fluoroaryl derivatives against oxidative DNA damage. ${ }^{26}$ In summary, novel fluoroarylbichalcophenes in the current study provided a significant antigenotoxic activity against the DNA-intercalation caused by $\mathrm{NaN}_{3}$ and prevented the adduct formation for B[a]P metabolites probably through inhibiting the microsomal-dependent activation of the mutagen.

\section{Acknowledgment}

This project was supported by King Faisal University, Deanship of Scientific Research, Grant 140078.

\section{Disclosure}

The authors report no conflicts of interest in this work.

\section{References}

1. Connor TH, Trizna Z. Pentamidine isethionate is negative in tests for microbial mutagenicity and chromosomal breakage in vitro. Toxicol Lett. 1992;63(1):69-74.

2. Stauffert I, Paulini H, Steinmann U, Sippel H, Estler CJ. Investigations on mutagenicity and genotoxicity of pentamidine and some related trypanocidal diamidines. Mutat Res. 1990;245(2):93-98.

3. Thuita JK, Karanja SM, Wenzler T, et al. Efficacy of the diamidine DB75 and its prodrug DB289, against murine models of human African trypanosomiasis. Acta Trop. 2008;108(1):6-10.

4. Ismail MA, Brun R, Easterbrook JD, Tanious FA, Wilson WD, Boykin DW. Synthesis and antiprotozoal activity of aza-analogues of furamidine. J Med Chem. 2003;46(22):4761-4769.

5. Wenzler T, Boykin DW, Ismail MA, Hall JE, Tidwell RR, Brun R. New treatment option for second-stage African sleeping sickness: in vitro and in vivo efficacy of aza analogs of DB289. Antimicrob Agents Chemother. 2009;53(10):4185-4192.

6. White EW, Tanious F, Ismail MA, et al. Structure-specific recognition of quadruplex DNA by organic cations: influence of shape, substituents and charge. Biophys Chem. 2007;126(1-3):140-153.

7. El-Sayed WM, Hussin WA, Ismail MA. Efficacy of two novel $2,2^{\prime}$-bifurans to inhibit methicillin-resistant Staphylococcus aureus infection in male mice in comparison to vancomycin. Drug Des Devel Ther. 2012;6:279-287.

8. El-Sayed WM, Hussin WA. Antimutagenic and antioxidant activity of novel 4-substituted phenyl-2,2'-bichalcophenes and aza-analogs. Drug Des Devel Ther. 2013;7:73-81.
9. Boschi D, Guglielmo S, Aiello S, Morace G, Borghi E, Fruttero R. Synthesis and in vitro antimicrobial activities of new (cyano-NNOazoxy)pyrazole derivatives. Bioorg Med Chem Lett. 2011;21(11): 3431-3434.

10. Hussin WA, Ismail MA, El-Sayed WM. Novel 4-substituted phenyl2,2'-bichalcophenes and aza-analogs as antibacterial agents: a structural activity relationship. Drug Des Devel Ther. 2013;7:185-193.

11. Wakselman C. Fluorinated organic compounds: synthesis and biological applications. Ann Pharm Fr. 1999;57(2):108-115.

12. Park BK, Kitteringham NR, O'Neill PM. Metabolism of fluorinecontaining drugs. Annu Rev Pharmacol Toxicol. 2001;41:443-470.

13. Kato T, Hakura A, Mizutani T, Saeki K. Anti-mutagenic structural modification by fluorine-substitution in highly mutagenic 4-methylquinoline derivatives. Mutat Res. 2000;465(1-2):173-182.

14. Maron DM, Ames BN. Revised methods for the Salmonella mutagenicity test. Mutat Res. 1983;113:173-215.

15. Saeki K. Anti-carcinogenic structural modification by fluorinesubstitution in aza-polycyclic aromatic hydrocarbons. Yakugaku Zasshi. 2000;120(12):1373-1385

16. Hong CE, Cho MC, Jang HA, Lyu SY. Mutagenicity and antimutagenicity of Acanthopanax divaricatus var. albeofructus. J Toxicol Sci. 2011;36:661-668.

17. Prieto P, Pineda M, Aguilar M. Spectrophotometric quantitation of antioxidant capacity through the formation of a phosphomolybdenum complex: specific application to the determination of vitamin E. Anal Biochem. 1999;269(2):337-341.

18. Youssef MM, Al-Omair MA, Ismail MA. Synthesis, DNA affinity, and antimicrobial activity of 4-substituted phenyl-2,2'-bichalcophenes and aza-analogues. Med Chem Res. 2012;21(12):4074-4082.

19. DeMarini DM, Hanley NM, Warren SH, Adams LD, King LC. Association between mutation spectra and stable and unstable DNA adduct profiles in Salmonella for benzo[a]pyrene and dibenzo[a,1] pyrene. Mutat Res. 2011;714(1-2):17-25.

20. Zeiger E. Identification of rodent carcinogens and noncarcinogens using genetic toxicity tests: premises, promises, and performance. Regul Toxicol Pharmacol. 1998;28(2):85-95.

21. Hartmann RW, Palusczak A, Lacan F, Ricci G, Ruzziconi R. CYP 17 and CYP 19 inhibitors. Evaluation of fluorine effects on the inhibiting activity of regioselectively fluorinated 1-(Naphthalen-2-ylmethyl) imidazoles. J Enzyme Inhib Med Chem. 2004;19(2):145-155.

22. Buhler DR, Unlu F, Thakker DR, et al. Metabolism and tumorigenicity of 7-, 8-, 9-, and 10-fluorobenzo(a)pyrenes. Cancer Res. 1982;42(11): 4779-4783.

23. Ismail MA, Bialy SA, Brun R, et al. Dicationic phenyl-2,2'bichalcophenes and analogues as antiprotozoal agents. Bioorg Med Chem. 2011;19(2):978-984.

24. Katoh Y, Nemoto N, Tanaka M, Takayama S. Inhibition of benzo[a] pyrene-induced mutagenesis in Chinese hamster V79 cells by hemin and related compounds. Mutat Res. 1983;121(2):153-157.

25. Collins AR, Azqueta A, Langie SA. Effects of micronutrients on DNA repair. Eur J Nutr. 2012;51(3):261-279.

26. Muzandu K, El Bohi K, Shaban Z, Ishizuka M, Kazusaka A, Fujita S. Lycopene and beta-carotene ameliorate catechol estrogen-mediated DNA damage. Jpn J Vet Res. 2005;52(4):173-184.
Drug Design, Development and Therapy

\section{Publish your work in this journal}

Drug Design, Development and Therapy is an international, peerreviewed open-access journal that spans the spectrum of drug design and development through to clinical applications. Clinical outcomes, patient safety, and programs for the development and effective, safe, and sustained use of medicines are a feature of the journal, which

\section{Dovepress}

has also been accepted for indexing on PubMed Central. The manuscript management system is completely online and includes a very quick and fair peer-review system, which is all easy to use. Visit $\mathrm{http}: / /$ www.dovepress.com/testimonials.php to read real quotes from published authors. 